\title{
Biomedical Waste and Solid Waste Management in the Time of COVID-19: A Comprehensive Review of the National and International Scenario and Guidelines
}

\author{
Malini R. Capoor ${ }^{1} \quad$ Annapurna Parida ${ }^{1}$ \\ ${ }^{1}$ Department of Microbiology and Biomedical Waste Unit, \\ Vardhman Mahavir Medical College and Safdarjung Hospital Delhi, \\ New Delhi, India

\begin{abstract}
Address for correspondence Malini R. Capoor, MD, Department of Microbiology, Vardhman Mahavir Medical College and Safdarjung Hospital, New Delhi 110029, India

(e-mail: rajeevmalini@rediffmail.com; malinircapoor@gmail.com).
\end{abstract}

J Lab Physicians 2021;13:175-182.

\begin{abstract}
Keywords

- COVID-19 waste

- biomedical waste

- solid waste

- guidelines

Biomedical waste generated during the diagnosis, isolation, and treatment of coronavirus disease 2019 (COVID-19) patients can also be the source of new infections; hence, it needs special consideration. Previous guidelines for the management of biomedical waste need to be revisited as the majority of COVID-19 patients remain asymptomatic and reside in community. Personal protective equipment (PPE) like masks, hazmat suits, gloves, and visors are now being used by the public also. Thus, the general household waste and disposables now make an exponential increase in the waste that can be considered an environmental hazard. In this article, the authors have tried to present the problems arising from COVID-19 waste and the recommendations put forth by competent authorities both nationally and internationally on COVID-19 waste management. Furthermore, in all the guidelines, it is crucial that the COVID-19 waste management follows environmentally sound principles and practices of biomedical waste management, with safe work and infection-control practices. Segregation of COVID-19 waste at source, awareness, and precautions at all steps of the waste-cycle are the only way ahead in this crisis.
\end{abstract}

\section{Introduction}

Basic waste management services were available in only $27 \%$ of health-care facilities in the least developed countries even before the coronavirus disease 2019 (COVID-19) pandemic hit the global population. ${ }^{1}$ By the time COVID-19 was declared a pandemic, cities around the world reported an increase of nearly five times in medical waste generation. ${ }^{2}$ This volume increase can be attributed to the increased use of personal protective equipment (PPE) globally. The outbreak of the novel coronavirus has not only exposed the poor health-care infrastructure in countries and the lack of preparedness to battle a pandemic but also loopholes in their waste management process.

Existing evidence points toward contact, droplet, and airborne as well as environmental spread from fomites and fecaloral routes of transmission of COVID-19. Only $15 \%$ of the affected have severe life-threatening pneumonia in COVID-19, while in the rest of the cases, the patient might be asymptomatic or may present with mild (common cold) or moderate forms of illness. ${ }^{3-5}$ Waste generated by patients in hospitals and the waste from households with COVID-19-infected patients can all be contaminated with blood, body fluids, or droplets. Sewage and waste water generated from these sources can also be considered published online June 28, 2021
DOI https://doi.org/

$10.1055 / \mathrm{s}-0041-1729132$ ISSN 0974-2727 (c) 2021. The Indian Association of Laboratory Physicians.

This is an open access article published by Thieme under the terms of the Creative Commons Attribution-NonDerivative-NonCommercial-License, permitting copying and reproduction so long as the original work is given appropriate credit. Contents may not be used for commercial purposes, or adapted, remixed, transformed or built upon. (https://creativecommons.org/licenses/by-nc-nd/4.0/).

Thieme Medical and Scientific Publishers Pvt. Ltd. A-12, 2nd Floor, Sector 2, Noida-201301 UP, India 
contaminated with the COVID-19 virus. To control the spread of COVID-19, the use of masks and PPEs, disposables, sanitizing liquids, and disinfectants has also increased. All these methods of precaution lead to an increased waste production and, as we all know, irresponsible waste management has led to disasters previously. ${ }^{6}$

As of the last week of December 2020, nearly 78 million people worldwide were diagnosed with COVID-19 and more than 1,727,000 had died. ${ }^{7}$ The number of COVID-19 cases is still on the rise; any further outbreaks due to improperly handled waste will just increase the problem. In this article, the authors have tried to present a comprehensive review of the national and international scenario and of all national and international guidelines on solid waste and biomedical waste (BMW) management during the COVID-19 pandemic.

\section{Magnitude of the Problem (National and International Scenario)}

With COVID-19, the fear of infection led to reduced effective segregation and, in some instance, even recycling of waste was prohibited. Furthermore, waste generated in homes increased and the chain of waste segregation and recycling was, in many instances, abandoned. According to the World Health Organization (WHO), before COVID-19 just over half (58\%) of the sampled facilities from 24 countries had adequate systems in place for proper BMW management. ${ }^{6}$ In low-income countries, proper segregation of hazardous and nonhazardous waste is not complete, which increases the volume of hazardous waste. COVID-19 has increased the problem of BMW management manyfold. Wuhan province of China, where the COVID-19 virus was first detected, experienced a surge of BMW production from 50 tonne per day before to 247 tonne per day during the pandemic. ${ }^{8}$ In April 2020, at least 14,500 tonne waste from health care was generated across Bangladesh because of the COVID-19 pandemic, out of which 206 tonne per day of medical waste was produced in Dhaka alone. 'Until the mid of July 2020, more than 2,600 tonne medical waste was collected from 91 designated COVID-19 hospitals, 8 residential centers, 24 temporary facilities, and self-quarantine households in south Korea that was disposed of by incineration on a priority basis. The drastic increase in COVID-19 waste from 5 million tonne per year to 2.5 million tonne per month in the United States is scary if not treated properly. ${ }^{10}$

According to a report filed by the Central Pollution Control Board (CPCB) in the National Green Tribunal in July, India generates 101 metric tonne (MT) of COVID-19-related BMW per day. This quantity is in addition to the regular BMW generation of $\sim 609$ MT per day. The report clearly states that the available capacity for incineration of COVID-19 BMW in the country is $\sim 840$ MT against the total generation of $\sim 710$ MT per day. New Delhi, the national capital of India, accounts for $11 \%$ of India's daily COVID-19 BMW generation. New Delhi has only two incinerators and $70 \%$ of their capacity is already utilized. As BMW gets segregated, the load on the incineration facilities gets reduced as more waste gets diverted to disinfection and recycling routes. It will not increase the capacity of incinerators but allow the BMW treatment facilities to handle more waste. ${ }^{11}$ Pre-COVID-19 total health-care waste production ranged from $1 \mathrm{~kg} / \mathrm{day} / \mathrm{bed}$ to $10-11 \mathrm{kgs} / \mathrm{day} / \mathrm{bed}$ (2 $\mathrm{kgs} /$ bed/day infectious waste) depending on the average income of a country. During COVID-19 pandemic, health-care facilities across the world reported nearly five times increase in the volume of waste produced..$^{8-10,12}$

\section{What Is COVID-19 Waste?}

BMW is defined as the waste generated during the diagnosis, treatment, or immunization of human beings or animals, in research, or in the production or testing of biological or in health camps..$^{13}$ Of the total amount generated, $85 \%$ is general waste and only $15 \%$ is considered hazardous waste, including infective waste (10\%), chemical, radioactive, cytotoxic, or sharps ( - Table 1) ${ }^{14}$ During this pandemic, the term COVID-19 waste is now used for any waste generated during isolation, diagnosis, treatment, quarantine, and home care of COVID-19 patients. Solid waste is considered infectious only if it is contaminated by the body fluids and secretions of COVID-19 patients; otherwise, uncontaminated solid waste is handled as per the Solid Waste Management Rules, 2016.

\section{COVID-19 Virus Survival in Environment}

The coronavirus SARS-CoV2 of the family Coronaviridae is responsible for COVID- $19 .{ }^{15}$ This virus is similar to the previous two viruses responsible for the severeacute respiratory syndrome (SARS) outbreak in 2003 and the Middle East respiratory syndrome (MERS) outbreak in 2012.16,17 WHO has categorized COVID-19 into risk group 2 in bio-hazard level. ${ }^{18}$ Kempf et al, in 2020, showed that the COVID-19 virus remains infectious for up to 72 hours on plastic and metal surfaces, up to 24 hours on cardboard, and for 4 hours on

Table 1 Categories of health-care waste as per the World Health Organization

\begin{tabular}{|c|c|}
\hline Waste category & Descriptions \\
\hline \multicolumn{2}{|l|}{ Hazardous waste } \\
\hline Infectious waste & $\begin{array}{l}\text { Waste contaminated with } \\
\text { blood, body fluid, or any other } \\
\text { material with the potential to } \\
\text { carry bacteria, virus, fungi, or } \\
\text { parasites }\end{array}$ \\
\hline Pathological waste & $\begin{array}{l}\text { Human anatomical tissue, } \\
\text { fetuses, organs, body fluids }\end{array}$ \\
\hline Microbiological waste & $\begin{array}{l}\text { Bacterial and viral culture, } \\
\text { stock, used media, quality } \\
\text { control reagents, serological } \\
\text { enzymes and equipment used } \\
\text { in microbiological laboratories }\end{array}$ \\
\hline Pharmaceutical waste & Expired or unused drugs \\
\hline Cytotoxic waste & Cytotoxic drugs \\
\hline Chemical waste & $\begin{array}{l}\text { Laboratory reagents, solvents, } \\
\text { cleaning agents }\end{array}$ \\
\hline Radioactive waste & $\begin{array}{l}\text { Radioactive isotopes, urine } \\
\text { and excreta of patients treated } \\
\text { with radioactive isotopes }\end{array}$ \\
\hline \multicolumn{2}{|l|}{ Nonhazardous waste } \\
\hline General waste & $\begin{array}{l}\text { Cardboards, plastic, and } \\
\text { thermocol packaging material, } \\
\text { paper, kitchen waste }\end{array}$ \\
\hline
\end{tabular}


copper. ${ }^{19}$ The COVID-19 virus can remain suspended in aerosol for more than 3 hours. Research has shown that both asymptomatic and symptomatic patients can shed the virus in feces even after they're declared cured. ${ }^{20,21}$

\section{Risk Associated with COVID-19 Waste}

Waste contaminated with COVID-19 patients' respiratory secretion, blood, and body fluids can be a potential source of infection. Without proper disposal guidelines, masks, PPEs, gloves, shields, and visors used by the public ${ }^{22}$ may end up in landfills, sewage, and water bodies. Fecal matter in populations without proper sewage facilities can contaminate the potable drinking water sources. In sewage systems, dense aerosol generation occurs at high-flow junctions. With heavy rainfall and floods, the sewer system might overflow, also increasing the risk of aerosol exposure. ${ }^{23}$ With many countries suspending recycling programs and opting for increased use of disposables, the amount of plastic waste has increased monumentally ( five times).,12 Without proper segregation,, if these end up in incineration or landfills, air, soil, and surface water quality will seriously deteriorate.

There is no evidence of COVID-19 transmission through waste handling but caution must be executed at every step of COVID-19 waste management. ${ }^{12}$ COVID-19 waste is a term designated for BMW generated during the diagnosis and care of COVID-19 patients. This approach of separate naming is adopted by many countries like India and the European Union for prompt treatment of COVID-19 waste. $^{24,25}$ The first step of waste management would be estimating the quantity and quality of waste produced. ${ }^{26}$ Increased volume of waste during the pandemic has overwhelmed the existing waste treatment facilities, as the total number of such facilities is still below the required amount in an average day. ${ }^{8,12,27}$ This pandemic should be taken as a learning experience and clear, honest data should be gathered at all steps to aid future policymakers. ${ }^{28}$ The "six r" policy (reduce, reuse, recycle, recover, refine, remanufacture) was proposed for waste minimization. This is also known as tackling "at source" than adopting "end-of-pipe" approach. Taking into consideration the method of disposal even before purchase (life-cycle thinking) of any item will help in selecting less wasteful materials (green purchasing). Every BMW article which is generated should go through a life-cycle assessment (LCA) report. This will help in efficient segregation and its most appropriate disposal. Extended producer responsibility (EPR)-a policy approach under which producers are given a significant responsibility for the collection and treatment of postconsumer products-is another method. More research is warranted in recycling and waste management solutions..$^{29,30}$

\section{Water, Sanitation, Hygiene, and Waste Management (WASH) Recommendation on COVID-19 Waste}

Taking the hazard level of COVID-19 and the previous WHO guidelines for waste management, WASH has recommended segregating general waste from COVID-19 biomedical waste. General waste generated in COVID-19-designated facilities or homes with COVID-19 patients carry no additional risk of transmission of infection. With proper precaution, they can be managed per general solid waste. A well-defined waste flow protocol based on the local government's guidelines should be devised. Color-coded, foot-operated, leakand corrosion-proof, double-lined bins should be available at the point of generation. ${ }^{13}$ Containers and bags should be appropriately labeled with signs like biohazard, toxic, corrosive, and highly infectious (-Table 2 ). Posters with easily understandable instruction should be available at all points of waste-handling sites. In the absence of onsite treatment options, designated storage areas should be created. Regular cleaning and disinfection of bins, trolleys, and storage areas, preferably twice daily, has been recommended for COVID-19 waste handling. Waste can be stored at the facility up to 48 hours, but most countries have advised the transfer of COVID-19 waste to treatment facilities on a daily basis. ${ }^{24}$ (National regulatory framework under BMW management

Table 2 Types of waste and final disposal methods as per the World Health Organization

\begin{tabular}{|c|c|c|c|c|}
\hline Waste & Color coding & Label & Container & Disposal \\
\hline Infectious waste & Yellow & $\begin{array}{l}\text { Highly } \\
\text { infectious }\end{array}$ & $\begin{array}{l}\text { Leak proof, } \\
\text { bags should be } \\
\text { autoclavable }\end{array}$ & $\begin{array}{l}\text { Autoclaving, microwaving, shred- } \\
\text { ding, and recycle after sterilization }\end{array}$ \\
\hline $\begin{array}{l}\text { Pathological or anatomical } \\
\text { waste, bandages, cotton, } \\
\text { beddings }\end{array}$ & Yellow & Biohazard & $\begin{array}{l}\text { Leak proof, nonchlo- } \\
\text { rinated bags }\end{array}$ & Incineration \\
\hline Sharps & Yellow & Sharps & $\begin{array}{l}\text { Puncture-proof } \\
\text { container }\end{array}$ & $\begin{array}{l}\text { Chemical sterilization, autoclaving, } \\
\text { mutilation, and recycle }\end{array}$ \\
\hline Cytotoxic & Yellow & & Leak-proof box & Incineration \\
\hline Radioactive waste & & & Lead box & Encapsulation \\
\hline Municipal waste & Black/green, blue & & Leak-proof bags & Composting, recycling, landfill \\
\hline
\end{tabular}


rules 2016 as amended mandate that BMW should not be stored in health-care facilities (HCFs) beyond 48 hours.) Vehicles transporting waste to offsite treatment plants also need to be appropriately labeled infectious, biohazard, toxic, and inflammable, as required. They must carry documentation of the waste class, waste source, pickup date, destination, driver's name, and number of containers or volume. ${ }^{31,32}$ In recent times, the global positioning satellite (GPS) system can also be used for real-time tracking of waste transport trucks.

Final disposal of COVID-19 waste: cost-effective and energy-efficient methods are preferable for the final disposal of BMW or COVID-19 waste. The State and Territorial Association on Alternate Treatment Technologies (STAATT) classification system has helped categorize the different methods of sterilization. ${ }^{13}$ COVID-19 virus is an enveloped virus-it can effectively be killed by any detergent or soap; hence, all recommended waste treatment options are good enough to sterilize any viable COVID-19 virus in both general and biomedical waste.

\section{Personal Protective Equipment (PPE) Use in COVID-19}

Before the COVID-19 pandemic, the most used protective equipment were masks and gloves. With the rise of respiratory virus pandemic in the last two decades, the use of masks by general public also increased. But COVID-19 pandemic brought out a landslide behavioral shift. General public and hospital employees both now use all forms of PPE. Gloves, masks, visors, face shields, splash-proof aprons, and full body suits are now readily available to the general public too. They now constitute a large part of the general municipal waste and BMW. In the hospital setup, their disposal method is predefined. Equipment made fully out of plastic material can be discarded with infectious recyclable plastic waste. They get sterilized by chemical or steam and are recycled at common BMW treatment facilities for material after mutilation. PPE made of 30\% polyethylene can be discarded with waste that is headed for incineration. WASH advises discarding these after mutilation into strong bags and handing over these bags to municipality waste collectors for further treatment. The European Union advised households with COVID-19-suspected or-confirmed patients to collect the masks in separate bags and hand them over to professional COVID-19 waste treatment facilities. ${ }^{25}$ In India, public and non-COVID-19 households are advised to store the masks in dry paper bags for at least 72 hours before mutilating and discarding them into general waste. ${ }^{24}$ As the demand for PPE overwhelms the supply, different guidelines have been put forward to disinfect and reuse PPEs. ${ }^{33,34}$ Fully plastic visors, goggles, and shields can be disinfected by $70 \%$ alcohol or $1 \%$ sodium hypochlorite. N95 masks can be reused in rotation four times by letting them dry in a brown paper bag for 72 hours. $^{34}$

\section{Laboratory Waste}

Microbiological laboratory waste is considered highly infectious (category 2). WHO recommends pretreatment of all laboratory waste before discarding it into color-coded containers for final disposal as category 1 infectious waste. ${ }^{13,35,36}$ COVID-19 diagnostic laboratories produce plastic wastes, such as pipettes, Eppendorf tubes, reagents, small polymerase chain reaction (PCR) tubes, and enzyme-mixed liquid. For this, all laboratories must be equipped with one dedicated waste autoclave or microwave. ${ }^{37}$

\section{Waste Treatment during COVID-19}

COVID-19 is an enveloped coronavirus easily killed by all available methods of waste treatment. Potentially infectious waste forms the bulk of biomedical hazardous waste. In STAATT classification, even level I includes killing of lipophilic/hydrophilic viruses whereas the commonly used waste treatment methods are level III. ${ }^{13}$

A. Steam treatment technologies: Autoclaves are preferred for small-scale onsite waste treatment. Prevacuum autoclaves are better for waste pretreatment for microbiological laboratories and need less time for disinfection. But they release steam before the treatment cycle, hence they should be associated with high efficiency particulate air (HEPA) filters at vents. ${ }^{37}$ For waste treatment, autoclaves must operate between 15 and 30 psi or 1,540 and 2,280 mmHg; a minimum recommended temperature-exposure time criterion of $121^{\circ} \mathrm{C}$ for 30 minutes was suggested for effective killing of all microorganisms. Efficiency of each autoclave cycle depends on time, temperature/pressure, process sequence, load size, stacking configuration and packing density, types and integrity of bags or containers used, physical properties of the materials, the amount of residual air, and the moisture content in the waste. ${ }^{38}$ Regular validation tests using biological indicators should be performed at periodic intervals (weekly or as per national guidelines).

B. Microwave treatment technologies: In this technique, waste is rapidly heated by microwave energy at 2,450 $\mathrm{MHz}$ and a wavelength of $12.24 \mathrm{~cm}$. Batch system microwave can handle 30 to $100 \mathrm{~L}$ of waste in 30 to 60 minutes. A semicontinuous microwave system can handle up to $250 \mathrm{~kg} /$ hour. $^{38}$ Unlike autoclaves, microwave can treat pathological tissue waste. ${ }^{39}$ Care has to be taken as flammables and radioactive substances should not be put in a microwave..$^{39,40}$

C. Dry-heat treatment technologies: This technique is capable of handling small volume of waste only. Furthermore, it is an energy-wasting method as it needs higher temperature and longer exposure. For quality control, Bacillus atrophaeus spores are commonly used as a microbiological indicator. ${ }^{39}$

D. Chemical treatment technologies: COVID-19 virus can be effectively killed by $70 \%$ alcohol, 1\% hypochlorite, and hydrogen peroxide. Freshly prepared solution of $1 \%$ sodium hypochlorite should be used and a minimum of 30 minutes should be given for treatment as mandated in BMW management rules, 2016, as amended. Alkaline hydrolysis is used mainly for cytotoxic, animal, and human tissue waste. ${ }^{13}$

E. Incineration: Incineration is a high-temperature dry oxidation process. Dry and high calorific value waste (at 
least $2,000 \mathrm{kcal} / \mathrm{kg}$ ) can be treated through this method. ${ }^{13}$ The greatest advantage is it reduces the volume of waste drastically.

F. Encapsulation and inertization: When no other method is feasible or available, waste can be kept in metallic drums sealed with plastic foam and stored or filled in landfill sites. This method is suitable for pharmaceutical or chemical waste.

G. Emerging technologies: Newer methods such as plasma pyrolysis, superheated steam, ozone, and promession can surpass the conventional technologies in places.

All of the discussed methods can kill the COVID-19 virus effectively, hence the already existing BMW treatment facilities can continue following the technologies preferred for their operation. The only difference noted between COVID-19 BMW and non-COVID-19 BMW was in regards to double-bagging (to prevent leakage) and labeling (to expedite its disposal at the common biomedical waste treatment facility [CBWTF] level)-seen as a common practice in India, the United Kingdom, and other countries. The solid waste whether from a COVID-19 or a non-COVID-19 facility is to be treated as general waste unless it is contaminated by patients' secretions or body fluids.

\section{Global Response to COVID-19 Waste}

The global response to the COVID-19 pandemic has been varied from complete apathy to full-blown panic. In most countries, preventive measures and health-care guidelines came only after the overall situation had worsened. Italian policymakers pushed for complete segregation of COVID-19 waste and other BMW or solid waste, whereas the United States recommended no extra steps for COVID-19 waste management. India has taken stance in the middle and has recognized a separate COVID-19 waste category only in health-care facilities, and expedited its treatment without any delay.

\section{India}

BMW management rules, 2016, and amendments 2018, 2019, are comprehensive rules made under the WHO core principles. Furthermore, the Kayakalp initiative of the Government of India was appreciated by WHO. ${ }^{1,41}$ Central Pollution Control Board (СРCB) of India brought out specific guidelines for the handling, treatment, and disposal of waste generated during treatment, diagnosis, and quarantine of COVID-19 patients on March 18, 2020. These guidelines were revised on March 25, 2020 (revision 1), followed by revisions on April 18, 2020 (revision 2), June 10, 2020 (revision 3), and July 17, 2020 (revision 4). ${ }^{24}$ These guidelines for the management of waste generated during the diagnostics and treatment of COVID-19-suspected or-confirmed patients are required to be followed by stakeholders in addition to the existing practices under BMW management rules, 2016, as amended. For COVID-19 waste, use of separate COVID-19 waste-labeled, color-coded, and foot-operated bins and trolley were advised. Use of double-layered bags for collection and transport is advised to prevent spillage or leaking. (Color categories of BMW as per BMW management rules, 2016, amendments 2018, 2019, and CPCB guidelines 2020 is depicted in - Table 3.) To reduce bulk meticulous segregation of general waste from BMW and reducing the use of disposables is advised. General waste generated in hospitals and isolation centers has to be segregated into wet and dry waste, which reduces the waste marked for incineration or landfills remarkably. ${ }^{42}$

The COVID-19 isolation/quarantine homes also need to follow the BMW guidelines as per BMW management rules, 2016, as amended. General waste (kitchen waste, tetra packs, cardboard boxes) have to be discarded as general waste. Used masks, gloves, and COVID-19 patients' blood- or body fluid-contaminated swabs from home quarantine or isolation centers should be treated as BMW and need to be collected in nonchlorinated yellow bags. PPEs, hazmat suits, and face shields should be collected in red bags. The wet and dry waste bags need to be sprayed with $1 \%$ sodium hypochlorite before being handed over to the designated waste collectors. ${ }^{42}$

The Indian government has further widened the regulation to include mortuaries, crematoriums, and graveyards in these COVID-19 waste management rules. PPEs, masks, and bags from these places also need to be considered BMW; if they are from health-care workers (HCWs), they can be collected in red/yellow bags, and if from the general public, they can be collected in the municipal blue bin and handed over to the municipality/local governing bodies.

The only point further advised to the public was to use reusable masks and discard only after 72 hours storage and

Table 3 Color category based on biomedical waste management rules, 2016, as amended, and Central Pollution Control Board guidelines, 2020, as amended

\begin{tabular}{|l|l|}
\hline Category & Type of waste \\
\hline Yellow & $\begin{array}{l}\text { Anatomical waste, animal waste, soiled } \\
\text { waste (blood and body fluid-soaked } \\
\text { cotton swabs, gauge), expired/discarded } \\
\text { medicine, chemical waste, beddings, } \\
\text { linen, head cover, shoe cover, masks, N95 } \\
\text { masks, gowns and personal protective } \\
\text { equipment made of woven material } \\
\text { with 30-40\% polyethylene plastic, and } \\
\text { nonchlorinated bags } \\
\text { Microbiology laboratory waste-labora- } \\
\text { tory cultures, stocks, blood bags, and } \\
\text { toxins }\end{array}$ \\
\hline Red & $\begin{array}{l}\text { Recyclable contaminated plastic waste- } \\
\text { gloves, goggles, face shields, visors, } \\
\text { tubings, bottles, catheter, urine bags, and } \\
\text { syringes without fixed needles }\end{array}$ \\
\hline $\begin{array}{l}\text { White (transparent } \\
\text { puncture-proof box) }\end{array}$ & $\begin{array}{l}\text { Contaminated needles, syringes with } \\
\text { fixed needles, scalpels, and blades }\end{array}$ \\
\hline $\begin{array}{l}\text { Blue leak-proof box } \\
\text { (glass) }\end{array}$ & $\begin{array}{l}\text { Contaminated broken glass bottles and } \\
\text { slides }\end{array}$ \\
\hline
\end{tabular}

a For disinfection of biomedical waste management (BMWM) articles, freshly prepared 1 to $2 \%$ sodium hypochlorite is recommended-slides, coverslip, and so forth.

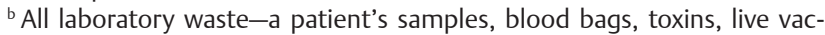
cines, cultures (liquid/solid), and devices used to transfer cultures-need pretreatment by autoclaving/microwaving/hydroclaving, then their respective category-plastic (red)/glass (blue)-is decided. 
mutilation. Effluent treatment plants were advised not to recirculate the treated water for any purpose. Use of PPE at all levels of waste handling is advised. Regular training sessions are being conducted for all workers and supervisors involved in BMW management. For effective communication, exclusive manpower and use of modern technology (mobile applications, barcoding, GPS tracking) has been made mandatory.

\section{United States of America}

Medical waste in the Unites States has been called regulated medical waste (RMW). Taking into consideration the WHO advisory on COVID-19 waste and that COVID-19 is not considered as a category A infective substance, Occupational Safety and Health Administration (OSHA) said that no extra steps are required while handling COVID-19 waste. ${ }^{43}$ General waste possesses no extra threat of COVID-19 transmission; hence, it can be treated as per the solid waste management policy established earlier. ${ }^{44}$ The only caution advised is for sanitation workers-to wear puncture-resistant gloves and face and eye protection while handling waste. Center for Disease Control and Prevention (CDC) also considered COVID-19 waste as any other RMW and advised following the local guidelines for its management. ${ }^{45}$ In comparison to developing and underdeveloped countries with less than $50 \%$ compliance to effective BMW management, this is suitable for a country like the United States where the BMW management procedure is better regulated.

\section{The European Union}

The European Union (EU) countries have efficient established BMW management practices. In most of the EU countries, this includes outsourcing to third party contractors. In this COVID-19 pandemic, many reports have come up on how these facilities were overwhelmed with the increased volume of waste. Keeping this concern in mind, a separate COVID-19 waste treatment facilities designation was recommended for prompt treatment of COVID-19 waste. ${ }^{25}$ To reduce the volume and for easy collection of waste, the general public was advised to collect masks worn by COVID-19-confirmed or-suspected patients separately from the caretakers and family members in paper bags. These bags would be handed over to the professional COVID-19 waste-handling facilities through designated COVID-19 waste collectors.

\section{Italy}

Italian authorities divided waste into T1 and T2. Waste collected from homes with COVID-19 patients is classified as $\mathrm{T} 1$ and is considered infectious. Waste from all other homes without any COVID-19 patients comes under the T2 category. T1 waste should be collected in double-layered bags and requires no at-source separation. No elderly person should be employed in the handling of $\mathrm{T} 1$ waste. T2 waste can be collected and treated as per the normal municipality waste-management guidelines. ${ }^{46}$ This method of disposal increases the volume of COVID-19 waste and can only be feasible for a small country such as Italy.

\section{United Kingdom}

At first, the fear of transmission had led to the suspension of recycling of waste in Britain. As per the Association of Cities and Region for Sustainable Resource Management, 83\% of waste-handling infrastructure has started functioning like before. No specific guidelines for BMW or solid waste were recommended except stringent protection while handling waste. $^{47}$

\section{United Nations Environmental Program (UNEP)}

UNEP recommends the three-S strategy-sorting, segregation, and storage. ${ }^{48}$ COVID- 19 waste needs to be separated from the general medical waste at the point of generation. Countries need to utilize a stop-gap policy. The first step would be assessing the volume of waste produced. Then they should follow the sustainability assessment of technologies (SAT) methodology to choose the best available technology (BAT). The aim should be preventing transmission of COVID-19 from waste and to follow the best environmental practices (BEP). UNEP advises that household waste from homes with COVID-19-confirmed patients should be considered infective. Such households should store the waste in scavenger and leak-proof containers that can be collected directly by waste handlers. ${ }^{49}$ Many third world countries follow the UNEP recommendations as national policy for waste management.

\section{South Korea}

On January 28, 2020, the Ministry of Environment in South Korea tightened the existing Wastes Control Act by introducing the Extraordinary Measures for Safe Waste Management against COVID-19. As per the new guidelines, COVID-19 waste could not be stored for more than 24 hours and must be incinerated on the same day of collection, whereas the earlier act gave 7 days of storage time for waste that can be incinerated within 2 days of delivery. Under the extraordinary measures for COVID-19 waste, household waste generated by self-quarantined persons would also be treated as COVID-19 waste. The guidelines were revisited after the health alert was raised to level 4 (on February 23, 2020), stating that the waste generated by home-quarantined patients would be stored in dedicated bags and containers after being treated by the disinfectant spray. ${ }^{50,51}$

\section{Future Consideration}

COVID-19 waste has brought out one very important aspect of policymaking in BMW management, that is, public participation and social responsibility. Increased home care of COVID-19 patients or increased chronically ill patients in the general population has increased the total volume of potentially infected biomedical and general waste. Public awareness about BMW and the importance of its segregation from general waste needs to be addressed. Sadly, policies of BMW management had always targeted only the medical community. The authors feel that health-care waste at home should now become a completely separate category of home-care BMW and is addressed depending on the volume and type 
collected. Data on this is nonexistent, as before the pandemic limited medical activities occurred at home. But during the pandemic, with increased door-to-door sample collection, cheaper long-term home-care options for chronically ill/older people, and self-administered medicinal devices, this waste volume will only increase with time. An efficient and prompt collection, treatment, and disposal of COVID-19 waste by following the full stipulated safety measures are the key to handle this infectious waste of increased quantum. Separate collection in double-seal designated bags/bins must be practiced by isolation wards, hospitals, quarantine centers, and home-quarantines. For a timely collection and disposal of home-care waste, the role of urban local bodies (ULBs) is quite important, albeit in the lockdown period many waste treatment facilities and ULBs are facing manpower crisis. Therefore, workers involved in this job must be considered as part of an essential service. Ensuring proper health care and safety measures should be the responsibility of all stakeholders, including the public. Awareness among people can be a panacea for safer handling of COVID-19 waste; hence, the government, local bodies, and waste treatment facilities must drive awareness programs using different media to directly reach out to the people. It is recommended that no COVID-19 waste should be disposed of by mixing with other household solid waste in closed containers/bins/bags. Segregation of BMW and solid waste (SW) streams is most crucial. On that basis, an integrated approach involving environmental engineers, healthcare workers, and researchers is imperative and is being recommended to overcome the challenges of COVID-19 waste management. Strategies such as "identify, isolate, disinfect, and safe treatment practices" have been found to be the way forward for safer management of COVID-19 waste.

Unregulated BMW management and solid waste management is a public health problem in the COVID-19 pandemic. This has posed a grave threat to not only human health and safety but also the environment. Safe and reliable methods for handling COVID-19 waste are of paramount importance. It is crucial that COVID-19 waste management follows environmentally sound principles and practices of BMW management with safe work- and infection-control practices. Strategies such as "identify, isolate, disinfect, and safe treatment practices" have been found to be effective for safer management of COVID-19 waste. Segregation of COVID-19 waste at the source, awareness, use of sustainable technologies, and precautions at all steps of the waste-cycle are the only way ahead in this crisis.

Author Contributions Malini R Capoor wrote the article and reviewed it, while Annapurna Parida added the data and tables.

\section{Details of Earlier Presentation \\ None.}

\section{Financial Disclosures \\ None.}

\section{Conflict of Interest}

None declared.

\section{References}

1 World Health Organization; UNICEF. WASH in health care facilities: global baseline report 2019. https://www.who.int/ water_sanitation_health/publications/wash-in-health-carefacilities-global-report/en/. Accessed September 27, 2020

2 You S, Sonne C, Ok YS. COVID-19's unsustainable waste management misguided forest action in EU Biodiversity Strategy as a biodiversity strategy. American Association for the Advancement of Science 2020;368(6498):1438-1439

3 Wang D, Hu B, Hu C, et al. Clinical characteristics of 138 hospitalized patients with 2019 novel coronavirus-infected pneumonia in Wuhan, China. JAMA 2020;323(11):1061-1069

4 Carlos WG, Dela Cruz CS, Cao B, Pasnick S, Jamil S. Novel Wuhan (2019-nCoV) coronavirus. Am J Respir Crit Care Med 2020;201(4):7-P8

5 García LF. Immune response, inflammation, and the clinical spectrum of COVID-19. Front Immunol 2020;11(June):1441

6 World Health Organization Web site. Health-care waste. https://www.who.int/news-room/fact-sheets/detail/ health-care-waste. Published February 8, 2018. Accessed August 25, 2020

7 WHO Coronavirus Disease (COVID-19) Dashboard. https:// covid19.who.int/. Accessed August 27, 2020

8 Singh N, Tang Y, Ogunseitan OA. Environmentally sustainable management of used personal protective equipment. Environ Sci Technol 2020;54(14):8500-8502

9 Rahman MM, Bodrud-Doza M, Griffiths MD, Mamun MA. Biomedical waste amid COVID-19: perspectives from Bangladesh. Lancet Glob Health 2020;8(10):e1262

10 Ilyas S, Srivastava RR, Kim H. Disinfection technology and strategies for COVID-19 hospital and bio-medical waste management. Sci Total Environ 2020;749:141652

11 National Green Tribunal. Compliance status report by СРCB in OA 72 of 2020 (in re scientific disposal of bio-medical waste arising out of COVID-19 treatment-Compliance of BMW Rules, 2016). https:/greentribunal.gov.in/sites/default/files/ news_updates/Complaince Status Report by CPCB in OA72 of 2020(In Re Scientific Disposal of Bio-Medical Waste arising out of COVID-19 treatment-Compliance of BMW Rules2016) 29.pdf. Accessed August 15, 2020

12 World Health Organization. Water, sanitation, hygiene, and waste management for SARS-CoV-2, the virus that causes COVID-19. Interim guidance 29 July 2020. https://www.who. int/publications/i/item/WHO-2019-nCoV-IPC-WASH-2020.4. Accessed August 24, 2020

13 Emmanuel J, Pieper U, Rushbrook P, et al. Safe management of wastes from health care activities. Bull World Health Organ 2014;79(2):171

14 World Health Organization. Safe management of wastes from health care activities: a summary. Bull World Health Organ 2017;26:3

15 Gorbalenya AE, Baker SC, Baric RS, et al. Coronaviridae Study Group of the International Committee on Taxonomy of Viruses. The species severe acute respiratory syndrome-related coronavirus: classifying 2019-nCoV and naming it SARS-CoV-2. Nat Microbiol 2020;5(4):536-544

16 Cheng VCC, Lau SKP, Woo PCY, Yuen KY. Severe Acute Respiratory coronavirus as an agent of emerging and remerging infection. Clinical Microbiol Review 2007;20(4):660-694

17 Alshukairi AN, Zheng J, Zhao J, et al. High prevalence of MERS-CoV infection in camel workers in Saudi Arabia. MBio 2018;9(5):1-10

18 World Health Organization. Laboratory bio risk management for laboratories handling human specimens suspected or confirmed to contain novel coronavirus: interim recommendations. https://www.who.int/csr/disease/coronavirus_ 
infections/Biosafety_InterimRecommendations_Novel Coronavirus_19Feb13.pdf. Published February 19, 2013. Accessed August 22, 2020

19 Kampf G, Todt D, Pfaender S, Steinmann E. Persistence of coronaviruses on inanimate surfaces and their inactivation with biocidal agents. J Hosp Infect 2020;104(3):246-251

20 Tang A, Tong ZD, Wang HL, et al. Detection of novel coronavirus by RT-PCR in stool specimen from asymptomatic child, China. Emerg Infect Dis 2020;26(6):1337-1339

$21 \mathrm{Xu} \mathrm{Y,} \mathrm{Li} \mathrm{X,} \mathrm{Zhu} \mathrm{B,} \mathrm{et} \mathrm{al.} \mathrm{Characteristics} \mathrm{of} \mathrm{pediatric} \mathrm{SARS-CoV-2}$ infection and potential evidence for persistent fecal viral shedding. Nat Med 2020;26(4):502-505

22 Ong SWX, Tan YK, Chia PY, et al. Air, surface environmental, and personal protective equipment contamination by severe acute respiratory syndrome coronavirus 2 (SARS-CoV-2) from a symptomatic patient. JAMA 2020;323(16):1610-1612

23 ten Veldhuis JAE, Clemens FHLR, Sterk G, Berends BR. Microbial risks associated with exposure to pathogens in contaminated urban flood water. Water Res 2010;44(9):2910-2918

24 Central Pollution Control Board. Guidelines for handling, treatment and disposal of waste generated during treatment, diagnosis, quarantine of COVID-19 patients, Central Pollution Control Board guidelines for COVID-19 waste management. https://cpcb.nic.in/uploads/Projects/Bio-Medical-Waste/ BMW-GUIDELINES-COVID_1.pdf. Published July 7, 2020. Accessed August 24, 2020

25 European guidelines on waste management in the context of the coronavirus crisis. https://ec.europa.eu/info/files/wastemanagement-contextcoronavirus-crisis_en. Published April 14, 2020. Accessed August 20, 2020

26 Emmanuel J, Pieper U, Rushbrook P, et al. Safe management of wastes from health care activities. Bull World Health Organ 2014;79(2):171

27 Harhay MO, Halpern SD, Harhay JS, Olliaro PL. Health care waste management: a neglected and growing public health problem worldwide. Trop Med Int Health 2009;14(11):1414-1417

28 Tudor TL. Towards the development of a standardized measurement unit for health care waste generation. Resour Conserv Recycling 2007;50:319-333

29 Van Calster G. Waste management in the EU. Research Handbook on Climate Change Mitigation Law. Cheltenham, United Kingdom: Edward Elgar Publishing;2015:361-372

30 Kaiser B, Eagan PD, Shaner H. Solutions to health care waste: life-cycle thinking and "green" purchasing. Environ Health Perspect 2001;109(3):205-207

31 United Nations. UN recommendations on the transport of dangerous goods, 16th ed. http://www.unece.org/trans/danger/ publi/unrec/rev16/16files_e.html. Published 2009. Accessed August 22, 2020

32 World Health Organization. Guidelines for Safe Disposal of Unwanted Pharmaceuticals in and After Emergencies. Geneva, Switzerland: World Health Organization; 1999

33 The National Institute for Occupational Safety and Health (NIOSH). Recommended guidance for extended use and limited reuse of $\mathrm{N} 95$ filtering facepiece respirators in healthcare settings. https://www.cdc.gov/niosh/topics/hcwcontrols/recommendedguidanceextuse.html. Accessed August 22, 2020

34 Ministry of Health and Family Welfare Government of India. Advisoryonre-processingandre-useofeye-protection-Goggles. https://www.mohfw.gov.in/pdf/Advisoryonreprocessingandreuseofeyeprotectiongoggles.pdf. Published May 27, 2020. Accessed August 15, 2020

35 Secretariat of the Basel Convention and World Health Organization. Preparation of National Health-Care Waste Management Plans in Sub-Saharan Countries: Guidance Manual Geneva, Switzerland: World Health Organization; 2005 Annexe 3
36 National Research Council, Safe disposal of infectious laboratory waste. Biosafety in the Laboratory: Prudent Practices for Handling and Disposal of Infectious Materials. Washington, DC: The National Academies Press; 1989

37 Capoor MR, Bhowmik KT. Current perspectives on biomedical waste management: rules, conventions, and treatment technologies. Indian J Med Microbiol 2017;35(2):157-164

38 Lemieux P, Sieber R, Osborne A, Woodard A. Destruction of spores on building decontamination residue in a commercial autoclave. Appl Environ Microbiol 2006;72(12):7687-7693

39 Emmanuel J, Stringer R, For Proper Disposal: A Global Inventory of Alternative Medical Waste Treatment Technologies. Arlington, VA: Health Care Without Harm; 2007

40 Devine AA, Grunden AM, Krisiunas E, et al. Testing the efficacy of a combination of microwave and steam heat for log reduction of the microbial load following a simulated poultry mass mortality event. Appl Biosaf 2007;12(2):79-84

41 Ministry of Environment, Forest, and Climate Change, Government of IndiaBio-medical waste management rules., Gazette of India. New Delhi, India: Department of Health Research; 2016: Part II, Section 3, Subsection (i)

42 Ministry of Environment, Forest, and Climate Change, Government of IndiaSolid Waste Management Rules. 2016 Gazette of India. New Delhi, India: Department of Health Research; 2016: Part II, Section 3, Sub-Section (ii)

43 Occupational Safety and Health Administration. COVID-19 control and prevention. https://www.osha.gov/SLTC/covid-19/ controlprevention.html\#solidwaste. Accessed August 20, 2020

44 Occupational Safety and Health Administration. COVID-19 control and prevention: solid waste and wastewater management workers and employers. https://www.osha.gov/ SLTC/covid-19/solid-waste-wastewater-mgmt.html. Accessed August 22, 2020

45 Centers for Disease Control and Prevention. Clinical questions about COVID-19: questions and answers. https://www.cdc.gov/ coronavirus/2019-ncov/hcp/faq.html. Accessed August 22, 2020

46 Italian guidelines on classification of waste. https://www. snpambiente.it/2020/03/24/emergenza-covid-19-indicazionisnpasulla-gestione-deirifiuti. Accessed August 22, 2020

47 National Association of Waste Disposal Officers (NAWDO) Association of Cities and Regions for Sustainable Resource Management. Coronavirus-restarting household waste recycling centre service. https://1ur6751k31sj3droh41tcsrawpengine.netdna-ssl.com/wp-content/uploads/2020/05/4April-2020-NAWDO-HWRC-reopening-guidance-FINAL.pdf. Accessed August 22, 2020

48 United Nations Environment Programme. Waste management during the COVID-19 pandemic: from response to recovery. https://www.unenvironment.org/resources/report/ waste-management-during-covid-19-pandemicresponse-recovery. Published August 12, 2020. Accessed August 28, 2020

49 United Nations Environment Programme. COVID-19 waste management factsheet, household medical waste management strategies. https://wedocs.unep.org/bitstream/handle/20.500.11822/32775/FS7.pdf. Accessed August 28, 2020

50 United Nation Economic and Social Commission for Asia and the Pacific. The safe waste treatment for COVID-19: lessons from the Republic of Korea, 2020. https://www.unescap. org/sites/default/files/200514\%20waste\%20management\% 20for\%20COVID-19\%28edited\%29\%20FINAL.pdf. Accessed September 27, 2020

51 Ministry of Environment-Republic of Korea. The guidelines of safe waste management for COVID-19 (English version), 2020. http://www.me.go.kr/ndg/web/board/read.do?menuId= 3284\&boardMasterId=156\&boardCategoryId=583\&boar dId=1362760. Accessed September 27, 2020 